\title{
ENVIRONMENTAL REPORTING ON THE WORLD WIDE WEB
}

\author{
Goranka Knežević, Marija Kostić, Predrag Vukadinović \\ Singidunum University, Faculty of business, Belgrade, Serbia
}

\begin{abstract}
:
This paper analyzes implementation and web reporting on environmental programs within corporate social responsibility policy of economic entities. Governments of EU Member States has to fulfil "environmental" obligations and establish further mechanisms by which they will oblige or motivate all relevant national entities - primarily companies - to actively work on the improvement of the environment. In that sense, we have compared and analyzed current situation in reporting on environment of our best economic entities within Belgrade Stock Exchange Index (Belex 15).
\end{abstract}

\section{Key words:}

web environmental reporting, environmental programmes, annual reports, sustainability reports, corporate social responsibility.

\section{INTRODUCTION}

One of the biggest challenges of the humanity during this century is going to be the achievement of sustainable development. Thus, huge part of the responsibility lays down on economic sector, because the destiny of the whole man-kind is mostly depending on business methods used in it, i.e. solving or causing problems affecting the whole society.

We could present corporate environmental responsibility in the widest sense as a way of economic entities' business, i.e. development of their innovative and economically sustainable products, processes and services, in accordance with needs of environment.

Since reporting on environmental responsibility is enabling more concrete inclusion of an economic entity in wider non-economic flows, in the paper we have analyzed current practice of economic entities in our country. We have limited our research to the use of electronic environmental reports and web sites as a presentation medium. While processing the topic, we have used both theoretic achievements and legal regulations in this field and researches of current practice of reporting of companies from non-financial sector in Serbia included in the calculation of Belgrade Stock Exchange index - Belex 15.

\section{ENVIRONMENTAL PROTECTION - GENERAL TRENDS WITHIN EUROPEAN UNION}

The need of environment protection is more and more prevailing the awareness of widest public, as well leaders of governments in states worldwide. Over the years numerous environmental aspects had been protected and their endangering is sanctioned increasingly. In European Union environmental policy belongs to shared competencies, meaning that $\mathrm{EU}$ institutions and governments of $\mathrm{EU}$ member states share responsibility in terms of its implementation. The goal of this policy is not only protection of environment in the current condition, but - after entry of The Lisbon Treaty on EU into force in 2009 - an obligation of its quality improvement was also introduced for the purpose of sustainable development establishment.

The EU legislator and powerful international organizations and institutions have expressed unquestionable support to adoption and implementation of the concept of sustainable development in the new millennium. Governments of Member States have accepted the obligation to define and implement measures on national levels in relation to presented imperative and there is no doubt about that any longer. However, concrete achievement of 
set objectives will exclusively depend on concrete measures and activities conducted daily. The burden of this responsibility is, above all, on economic entities as stakeholders, since their activities have the strongest influence on quality of lives of individuals and their environment.

The Lisbon Treaty affirms determination of the European legislator towards continuous and progressive expansion of requirements and raise of environmental standards and improvement of environment quality. This further indicates permanent increase in obligations for Member States' governments, but also all their socially responsible stake-holders to undertake apropriate environmental measures and activities. Therefore, it is more than desirable for companies to improve the quality of environment through implementation of environmental plans within their corporate social responsibility - and even more than determined by regulations [Kostić, $\mathrm{M}$. and Gasmi, G., 2010]. Up to now we have tried to give arguments for the importance of corporate social responsibility and environmental responsibility implementation. But the fact is that companies realistically do not have strong reasons to do so, since their main goal is to make profit. Even if they determine to implement environmental programmes within their corporative social responsibility, companies will do so for the purpose of their own positive marketing and establishment of positive relations with the public. Companies which really consider that through environmentally positive and sustainable methods of production and services providing they will, at the same time, achieve, i.e. increase profits, are oriented to corporate social performance of activities, not to corporate social responsibility [Hay, B., Stavins, R.N., 2005]. Unlike corporate social responsibility, corporate social performance presents "strategic" behaviour of the firm (i.e. any business entity) in the sense of ",configuration of principles, processes and policies and their noticeable outcomes in regard to social relations" [Reinhard, F., 1999], with a vision that such behaviour will lead to increase of owner's profit. Such strategic determination is characteristic for manufacturers of products and services marked with eco-label [Kostić, M., 2009].

\section{ENVIRONMENTAL REPORTING USING THE WWW}

\section{Environmental reporting in Serbia using WWW- legal requirements}

Environmental reporting by Serbian companies can be presented in annual reports as an official form of transmitting accounting information, or in supplemental reports. Certain requirements of the Law exist in this area of reporting. Annual reports of Serbian companies required to follow IFRS/IAS consist of Balance Sheet, Income Statement, Cash flow Statement and Statement of Changes in Equity. All these reports are prepared in accordance with the Rulebook on the content of items comprising Balance
Gazette of the Republic of Serbia No.53/2004, 11/2005, 51/2005). It means that Serbian companies use standardized financial statements. Law on Accounting requires that large companies should make their financial statement visible to users and all of the companies use the web site as a reporting medium, because of its global visibility and good quality of presentation of the reports. Although, Law does not prescribe which medium to use to make the reports visible. Serbian companies have chosen to present their annual reports as a hard copy version and as a web based version. In regular annual reports companies do not present any environmental information. That is why this report is supplemented by additional reports used to show environmental information. There is no law governing these issues and reports are prepared on a voluntary basis. In Serbia those reports are required in the case when company is included in some general projects for environmental preservation (for example projects by UN Compact Group). Company is then required to improve its environmental information transmission as a part of the results of the project. In this specific case, additional report on environment is presented in electronic form, especially through company's web site. From the above mentioned, we can conclude that regulative framework in Serbia for environmental reporting is at a very low level in a sense that it does not facilitates the transmission of that kind of information by Serbian companies. The practical research conducted and presented in the following paragraphs would reveal additional facts about the development stage in environmental reporting in Serbia using the World Wide Web.

\section{Research Methodology and Criteria for Companies' Ranking}

Theoretic elaborations in this paper are supplemented by the analysis of environmental reporting using the web sites and annual reports by Serbian economic entities belonging to non-financial sector of economy, and included in calculation of Belgrade Stock Exchange Index, known as Belex 15. Non financial sector of this Index consists of 12 entities. The research was limited to companies of non-financial sector because we consider them as biggest potential polluters, and these companies and their practice should be examples to others if we speak of reporting on environmental issues.

The basic research methodology is content analysis. Orientation to this type of secondary data collection resulted from the fact that we use information readily available on corporate websites. Content analysis has been widely used in the literature examining non financial disclosure behaviour (Unerman, 2000).

\section{Results of the Research}

Non financial sector companies from Belex 15 Index include the following 12 companies: NIS, ad, Sojaprotein, Energoprojekt Holding, a.d, Imlek a.d., Metalac, a.d, 
Aerodrom Nikola Tesla, a.d., Tigar, a.d., Galenika fitofarmacija, Alfa plam, a.d., Veterinarski zavod Subotica, a.d., Goša Montaža and Jedinstvo Sevojno. These companies represent $80 \%$ of a Belex 15 sample.

There are 3 different methods in which web is used for environmental reporting [3, pg. 13]. "Piggy back" method is paper based environmental report hosted within the company website as PDF. Integrative approach is the "piggy back" version to which HTML version is added with some specific facilities (email, live graphics etc.). The "stand alone" method is the one where hard copy is abandoned and reporting is solely on the web. According to the results of the research and content analysis applied we found that only one company, NIS, Naftna industrija Srbije uses Integrated method, while other 11 companies from the sample use some variation of all of these methods or some internal method not classified by the Certified Accountants Educational Trust [3, pg. 13].

In order to explain this matter further, we investigated the quality and content of website media used by NIS, and then we discussed on the other methods used in this respect by other Serbian companies from the sample.

TABLE NO. 1. Structure and quality of environmental information presented using Web based reports by NIS, Naftna industrija Srbije

\begin{tabular}{|c|c|}
\hline & NIS, Naftna industrija Srbije \\
\hline Navigation & $\begin{array}{l}\text { "drill down" approach where informa- } \\
\text { tion is presented on various levels and } \\
\text { with various details }\end{array}$ \\
\hline Site maps & $\begin{array}{l}\text { site map is presented and directs users } \\
\text { through web site }\end{array}$ \\
\hline Location & $\begin{array}{l}\text { environmental information presented } \\
\text { under the "sustainable reporting" sec- } \\
\text { tion }\end{array}$ \\
\hline Menus & $\begin{array}{l}\text { NIS presents menus where all sections } \\
\text { can be accessed easily }\end{array}$ \\
\hline $\begin{array}{l}\text { Previous } \\
\text { report }\end{array}$ & 3 years report presented \\
\hline $\begin{array}{l}\text { Different lan- } \\
\text { guage version }\end{array}$ & English, Russian and Serbian \\
\hline
\end{tabular}

Source. Authors own calculations from the database

As we can see from the table No.1 only Naftna industrija Srbije presents environmental information that is structured adequately and we evaluate the usage of a website corresponding to the several criteria levels- Navigation, Site maps, Location, Menus, Previous year reports and different language versions. According to the above mentioned criteria we can conclude that NIS follows all of the criteria and website has a very good quality in presenting the environmental information.
TABLE NO. 2. Advanced elements of web based reports used by NIS, Naftna industrija Srbije

\begin{tabular}{|l|c|}
\hline & $\begin{array}{c}\text { NIS, Naftna industrija } \\
\text { Srbije }\end{array}$ \\
\hline Regular updates & Yes \\
\hline Forums and bulletin boards & No \\
\hline Video and audio clips & Yes \\
\hline Related documents & Yes \\
\hline Quizzes and games & No \\
\hline $\begin{array}{l}\text { On line ordering of a hard } \\
\text { copy reports }\end{array}$ & No \\
\hline Hyperlinks & Yes \\
\hline
\end{tabular}

Source: authors own calculations

It is obvious that NIS succeeded in adding advanced elements such as regular updates, video clips (management interview regarding environment), related documents and hyperlinks to other pages.

TABLE NO. 3. Other methods used by Serbian non-financial Belex 15 companies in presenting the environmental information

\begin{tabular}{|c|c|c|}
\hline Company & Method & $\begin{array}{l}\text { No of com- } \\
\text { panies }\end{array}$ \\
\hline $\begin{array}{l}\text { Veterinarski } \\
\text { zavod Subotica }\end{array}$ & $\begin{array}{l}\text { One page, general } \\
\text { information regarding } \\
\text { corporate responsibility }\end{array}$ & 1 \\
\hline Sojaprotein & $\begin{array}{l}\text { One page, general } \\
\text { information regarding } \\
\text { corporate responsibility }\end{array}$ & 1 \\
\hline Imlek & $\begin{array}{l}\text { "Coming soon" method } \\
\text { ISO } 14001 \text { certificate } \\
\text { mentioned }\end{array}$ & 1 \\
\hline $\begin{array}{l}\text { Aerodrom Niko- } \\
\text { la Tesla, Alfa } \\
\text { Plam }\end{array}$ & $\begin{array}{l}\text { No information available } \\
\text { on the website }\end{array}$ & 2 \\
\hline $\begin{array}{l}\text { Galenika fito- } \\
\text { farmacijaTigar, } \\
\text { Metalac }\end{array}$ & Environmental policy & 3 \\
\hline $\begin{array}{l}\text { Jedinstvo } \\
\text { Sevojno, Goša } \\
\text { Montaža }\end{array}$ & $\begin{array}{l}\text { Certificate mentioned } \\
\text { ISO } 14001\end{array}$ & 2 \\
\hline
\end{tabular}

Source: Authors own calculations

Methods used vary from the "coming soon" to the one page where general information about environment and social responsibility matters are presented. There are even more companies that do not present any information regarding environment besides mentioning the ISO 14001 certificate that these companies had been given.

We may conclude from previously presented facts that Serbian economic entities have not yet recognized all advantages of reporting on environment using annual or supplemental reports within their websites. 


\section{CONCLUSION}

Although domestic practice of reporting on environmental responsibility shows significant improvements, it cannot be said that Serbian companies have dedicated their attention to reporting on environmental information using corporate web sites. Compared with the NIS as a "best practice" company leads us to conclusion that there is a much room for improvement and much of a knowledge that our companies still have to apply in the environmental reporting area.

\section{LITERATURE:}

[1] Bruce LH, Robert NS, Vietor RHK (2005). Environmental Protection and the Social Responsibility of Firms: Perspectives from Law, Economics and Business, Resources for the Future. Washington DC.

[2] Reinhard, F. (1999) Bringing the Environment Down to Earth, Applying Business Principles to Environmental Management, Harvard Business School Press.

[3] Certified Accountants Educational Trust (2001). Environmental, Social and Sustainability reporting on the World Wide Web: A guide to best practice. London.
[4] Unerman J. (2000) Reflections on quantification in corporate social reporting content analysis, Accounting, Auditing and Accountability Journal, vol. 13, No. 5, p 667-681

[5] Kostić M (2009). Eco-label as a form of information on products. Business Law and European Integrations. Law and Economy 5-8: 89-92 (in original: Eko-oznaka kao vid informacije o proizvodima. Pravo i privreda 5-8: 89-92)

[6] Kostić M, Gasmi G (2010). The Lisbon Treaty on EU and Corporate Responsibility and Environmental Responsibility. Law and Economy 7-9: 350-360 (in original: Lisabonski ugovor o EU i korporativna društvena i ekološka odgovornost. Pravo i privreda 7-9: 350-360)

[7] Consolidated versions of the Treaty on European Union and the Treaty on the Functioning of the European Union. OJ. of the EU2008/115/01http://www.consilium.europa. eu/showPage.aspx?id=1296\&lang=en (accession date: Feb., 2014)

[8] Rulebook on the content of items comprising Balance Sheet, Income Statement and Cash flow Statement, Official Gazette of the Republic of Serbia No.53/2004, 11/2005, 51/2005. 